\title{
THE COMMON USED OF FIGURATIVE LANGUAGES IN BEATLES' MASTERPIECES
}

\author{
Priyoto \\ Foreign Language High School (STBA) Pertiwi Jakarta, Indonesia \\ E-mail: pri_ck4@yahoo.co.id \\ Panji Armando \\ Foreign Language High School (STIBA) IEC Jakarta, Indonesia
}

\begin{abstract}
APA Citation: Priyoto \& Armando, P..(2018). The common used of figurative languages in Beatles' Masterpieces. Journal of English Language and literature, 3(2), 35-53.doi: 10.37110/jell.v3i2.50.
\end{abstract}

Received: 10-02-2018 Accepted: 01-06-2018 Published:01-09-2018

\begin{abstract}
This research is attempt to study about the common used of figurative languages in Beatles masterpieces. This research has three objectives: (1) to find out figurative languages in Beatles' Masterpieces especially "A Day In The Life" and "A Hard Days Night" song, (2) to know what is the literal meaning in Beatles' masterpieces especially "A Day In The Life" and "A Hard Days Night" song, (3) to know the moral values in Beatles' masterpieces especially " $A$ Day In The Life" and "A Hard Days Night" song. This research uses a descriptive qualitative method. The technique of data analysis is categorizing, sorting, coding, interpreting, drawing a conclusion, and representing the findings. The result of this research shows that The Beatles is common used hyperbole and pleonasm in both song lyrics. Based on the analysis, the writer hopes that this research can provide knowledge about figurative language that the readers can take positive things especially in works of art.
\end{abstract}

Keywords : Figurative language, master peace, literal meaning

\section{INTRODUCTION}

Song is one of essential things in human's life. It is the way people to express their feelings. Song affects human's life and become a media entertainment that people most love. Song usually tells about feeling, politic, life, and many more that represents the writer, singer, and music lovers. People generally listen to song when in trouble, sadness, happy or just want to hear it to appear a spirit in them. It means that song involves human's life. In this era, there are many songs about anything 
but not all of them are good and meaningful.

A lyric is written to be sung to the rhythm of the music which accompanies it. The melody is important and the words are structured into the refrain, verse, chorus, and bridge (Davies, 2009).

From the quote above, it proves that lyric is one of important elements of song. By understanding the lyric, we can understand the contents of song as well as the story behind. Moreover, lyric is an interesting part of song, because a song will be more special by using classy words or figures of speech within. There are a few ways that we can use to review the lyric and to know what figure of speech are used in a song, one of them is by knowing what figurative language is.

Learning figurative language is an interesting thing for people who love literary works because figurative language is part of literature. Furthermore, Figurative language is easy to find when we are studying poetry, novel, drama, song, and artistic things. There are a lot of things that we can use in literary works if we have knowledge of figurative languages. We can identify what figures of speech that most common used by poet, songwriter, etc. In addition when we want to write such a literary works, we can use figures of speech for developing our delivery and idea. Especially in this opportunity, the writer wants to introduce one of the greatest musicians in the world who has a lot of loyal fans, great works, and masterpieces. They are The Beatles.

As USA TODAY, The Nation's No. 1 Newspaper, puts it, "The Beatles have never lost their standing as the world's most influential and popular band. They've sold more records than any act in U.S. history (Roberts, 2011).

The Beatles were an English rock band formed in Liverpool in 1960. John Lennon, Paul McCartney, George Harrison, and Ringo Starr were members of The Beatles. The Beatles were a famous band in the world, their popularity started by their first hit single "Love Me Do" in album "Please Please $M e$ " as their first album. As long as their career, The Beatles released 12 albums until their break-up in 1969. After that, they made musical works in each solo career. John Lennon was shot and killed in December 1980 and George Harrison died of lung cancer in November 2001. Paul McCartney and Ringo Starr are surviving and still active in music. Songs by The Beatles until now still played by people who love them and they called "Beatle mania" is a base fan of The Beatles.

A masterpiece is a work of art that is carefully thought through and crafted to near perfection. It is a work 
that has occupied someone's mind, time, and energy for a long time (Mpanza, 2014).

For this purpose, the writer invites the reader to know masterpieces of the Beatles. Rolling Stones magazine mentioned that The Beatles have the greatest songs during 1960-1970, but the writer will focus on "A Day in The Life" and "A Hard Days Night" song as two of songs of Beatles' masterpieces.

After listening the songs, the writer finds some problems concerning with the Beatles songs. The first one is the literal meaning in Beatles' masterpieces especially A Day in The Life and A Hard Days Night likes. The second one is What figurative language is revealed in Beatles' Masterpieces especially A Day in The Life and A Hard Days Night. The third one is the moral value in Beatles' Masterpieces especially A Day in The Life and A Hard Days Night.

The aim of this study is the first is to know the literal meaning in Beatles' masterpieces especially A Day in The Life and A Hard Days Night likes.. The second is to know what figurative language is revealed in Beatles' Masterpieces especially A Day in The Life and A Hard Days Night . The third is to find out the moral value in Beatles' Masterpieces especially A Day in The Life and A Hard Days Night.
The writer will introduce to the reader about theories which affects in this research, then in this chapter writer will review the theory of Figurative language and kinds of figurative languages and moral value. All those theories are according to experts and used as guidance in conducting the research.

After knowing how interesting figurative language is, writer will try to tell the definition of figurative language according to experts. Furthermore, in this chapter the reader will know types of figurative language.

"Figurative Language is a type of language that varies from the norms of literal language, in which words mean exactly what they say. Also known as the "Ornaments of language, "Figurative Language does not mean exactly what it says, but instead forces the reader to make an imaginative leap in order to comprehend an author's point" (Westmoreland, 2010).

Figurative Language is all playwrights - in fact all writers make use of figurative language. That is, playwrights state things in other than literal ways. The playwright explains his ideas by the use of analogies which can be presented in different ways (Russel, 1996). 
Based on above elaboration about definition of figurative language, it can be inferred that figurative language is another way to write or say something by comparing it with something else but does not change the meaning. Figurative languages are usually found in song, poetry, drama, and others because by using figurative language, it makes your pieces of writing more interesting than using general words

There are many different methods, called figurative devices or literary devices, by which figurative language can be used. These are very often found in a song, and identifying figurative language is an integral part of literary analysis. Furthermore, being familiar with figurative language and figurative devices is important for composer and singer. This list of figurative devices will introduce you to figurative language that usually found in a song.

1. Simile

Simile is a figure of speech in which a comparison is expressed by the specific use of a word or phrase such as: like, as than, seems or as if.

For instances:

- We ran as if to meet the moon

- Like an old-stone savage armed

2. Metaphor
Metaphor is when an imaginative comparison between two unlike items does not include like or asthat is, when it says " $a$ is b" rather than "a is like b".

For instances:

- A woman is admired for her strength and beauty, she is a silken tent

- The stages of love are stepping stones to death

3. Hyperbole

Hyperbole is intentional exaggeration-saying more than is actually meant.

For instances:

- Dr. Johnson drank his tea in oceans

- My date last night was the most beautiful girl in the world

4. Personification

Personification is a special kind of comparison, closely related to metaphor that gives life or human characteristics to inanimate objects or abstract ideas.

For instances:

- $\quad$ The tree watches him sleep

- Night enfolded the town in its ebon wings

5. Paradox

A statement or situation containing apparently contradictory incompatible elements, but not closer inspection may be true. 
For instances:

- A well-known secret again

- Men work together whether

6. Sinisme they work together or apart

The allusive form that has doubt form which mockery someone's sincerity

7. Synecdoche

Synecdoche is a figure of speech that mentions a part of something to suggest the whole or contrary.

For instances:

- Have you got your wheels, Man? ("Wheels" is used to mean a car)

- 50 head of cattle ("Head" is used to mean whole animals)

8. Metonymy

Metonymy is figure of speech consists of using the name one thing for something else with which associated

For instances:

- I spent the evening reading Shakespeare

- White House (The president of the United States and advisors)

9. Allusion

Allusion is a brief figurative or symbolic reference within a literary text to a familiar or person, place, event or thing outside the text. Allusion is used in hopes of triggering an association to portray a meaning.
For instances:

- Catherine is a real Cinderella (works a lot around the house , cooking and cleaning)

- He was Hercules of a man (Strong, take on anything)

10. Irony

Irony is word using that say something other than what we mean actually. Irony is one of type of figurative language that declare the opposite meaning or contradiction with the fact

For instance:

- In this cell we are happy, actually

- The lady was lonely in the middle of a bustling city

11. Idiom

Idiom is the language peculiar to a group of people and has a special meaning of its own

For instances:

- She sings at the top of her lungs

- Do you need a hand?

12. Pleonasm

Pleonasm is figurative language that uses words improperly to emphasize meaning of word (Keraf, 1994: 145).

For instance:

- He falls down to the ground

The writers will give a discussion what moral value is. The theories related to moral value. 
Fietcher (1996:29) revealed that moral is decision cannot be made on the basis that some things always are right and some things always are wrong, rather, each moral decision should be meet in view of the specific situation on the basis of love.

According to Hazlitt (2003:111), A morality is sacrifice from little goodness to big goodness.

Meanwhile, according to Bentham, Morality is art to maximize happiness; it can be seen by achieving the existence of happy and joyful life of all people.

According to Stemberg (1994:938), morality refers to concern with what is good or right in people's relationships each other. A key to understanding morality is to be specific about definition of good (or bad) and right (or wrong).

Based on above elaborations the definition of moral value, It can be inferred that Moral value is the way people to identify whether it is wrong or right.

\section{Types of Moral Values}

Moral values are divided into several parts (Webster). The function from parts of moral values will use to analyze what moral values in The Beatles' Masterpieces selected songs. Because of that writer just includes part of moral values that related to selected songs in Beatles' masterpieces as a main discussion.

1. Love and Affection

Love is fell affection for. Love is a communications code word for the letter. Affection is action of affection or state of being affected.

2. Perseverance.

Perseverance is the action or the fact or an instance of persevering, continued or steadfast pursuit or prosecution of an undertaking or aim.

3. Sacrificing for Other

Sacrifice is something consecrated and offered to God or to a divinity or an immolated victim or an offering of any kind laid on an altar or otherwise presented in the way of religious, thanksgiving, atonement, or conciliation.

4. Self-Confidence

Self-Confidence is Confident in one self. Self-confident is confident of one's own strength or ability.

5. Strong Belief

Strong is able to bear or endure; able to with-stand stress or violence; having or exibiting moral or intelectual force, endurence or vigor. Belief is a state or habit of mind in which 
trust, confidence, reliance, is place insome person or thing.

6. Togetherness

On the contrary, this happens primarily in the family, and not in the bureaucratic context of schools. In addition, the duration and intensity of family togetherness far exceeds the togetherness which children experience in other social instituations (Wakenhut, 1985).

7. Kindhearted

Kind is the equivalent of what has been offered or received. Kind is applying more often to the disposition to sympathy and helpfulness. Kindly is stressing more the expression of the sympathetic, helpful nature, mood or impulse (a kind person with a kindly interest in the problem of other). Kindhearted is having sympathetic nature: Humane, compassionate. Kindheartedness is the quality or state of being kindhearted.

8. Peace-Loving

Peace is harmony in human or personal relation. A mental or spiritual condition marked by freedom from disturbance or oppressive thoughts or emotion. Loving word is from love, a lover section or attitude.
In the chapter previously, Writer discuss about the theory of Figurative language and Moral value. Those theories are related to the research and will help to conduct the research. In the next chapter, writer will discuss more intimate in analyzing by using those theories.

\section{METHODS}

The research uses the method of qualitative research. Research is a structured enquiry that utilizes acceptable scientific methodology to solve problems and create new knowledge that is generally applicable (Kumar, 2005).

Qualitative research is characterized by its aims, which relate to understanding some aspect of social life, and its method which generate words rather than number, as data for analysis (Cochran, 2002).

Qualitative data analysis is the process in which we move from the raw data that have been collected as part of the research study and use it to provide explanation, understanding, and interpretation of the phenomena of people and situations which we are studying.

\section{RESULTS AND DISCUSSION}

The writer presents the result of the research from the data sources. It involves the figurative language, the 
literal meaning and the moral value of Beatles' masterpieces especially "A Day In The Life" and "A Hard Days Night" song. Therefore, the writer puts the lyric of Beatles' selected masterpieces songs as sources to be analyzed as follow:

1. A Day in The Life

I read the news today, oh boy

About a lucky man who made the grade

And though the news was rather sad

Well, I just had to laugh

I saw the photograph

He blew his mind out in a car;

He didn't notice that the lights had changed

A crowd of people stood and

stared

They'd seen his face before

Nobody was really sure if he was

from the House of Lords

I saw a film today, oh boy;

The English army had just won the war

A crowd of people turned away

But I just had to look

Having read the book

I'd love to turn you on

Woke up, fell out of bed

Dragged a comb across my head

Found my way downstairs and

drank a cup

And looking up, I noticed I was late

Found my coat and grabbed my

hat

Made the bus in seconds flat

Found my way upstairs and had a

smoke

And somebody spoke and I went

into a dream

Ah I read the news today, oh boy

Four thousand holes in Blackburn,

Lancashire

And though the holes were rather small

They had to count them all

Now they know how many holes it takes to fill the Albert Hall

I'd love to turn you on

2. A Hard Days Night

It's been a hard days night, And I been working like a dog It's been a hard days night I should be sleeping like a log But when I get home to you I find the things that you do Will make me feel alright You know I work all day To get you money to buy you things

And it's worth it just to hear you say

You're going to give me everything

So why on earth should I moan

Cause when I get you alone

You know I feel ok 
When I'm home everything seems to be right

When I'm home feeling you

holding me tight, tight

Yeah!

You know I feel alright, you know

\section{I feel alright}

Then, Writer tries to

determine figurative languages by using the lyric of Beatles selected masterpieces songs as above.

\section{Figurative Language Types in lyrics of The Beatles' Masterpieces}

\section{a. A Hard Days Night}

A Hard Days Night is a song of The Beatles in their first career and where The Beatles was in especially "A Day In The Life" and "A Hard Days Night" song.

Writer notices that many types of figurative languages in literary works, one of them is in the song. In a song usually found figurative language types are designed by song writer to make it more poetical as well as interesting impression. Furthermore, writer finds figurative language types which used by The Beatles in process of creating a song, especially writer will analyze "A Day In The Life" and "A Hard Days Night" Song.

glorious period. This song uses figures of speech in the lyrics hence writer finds figurative language types in this song, they are Simile and Hyperbole.

\begin{tabular}{|l|l|}
\hline \multicolumn{2}{|c|}{ Table 1} \\
\hline \multicolumn{1}{|c|}{ Lyric } & \multicolumn{1}{c|}{ Type } \\
\hline And I been working like a dog & Simile \\
\hline And I should be sleeping like a log & Simile \\
\hline I work all day & Hyperbole \\
\hline You're going to give me everything & Hyperbole \\
\hline
\end{tabular}

Table 1. Figurative languages found in "A Hard Days Night"

Writer identifies two lyrics in A Hard Days Night song are use simile and the rest of two are hyperbole. Simile and hyperbole in the lyric are appears two times. The song tells about romance and sacrifice. 
Priyoto \& Armando, P.,

The common used of figurative languages in Beatles' Masterpieces

\section{b. A Day In The Life}

A Day In The Life is a song of The Beatles in their middle career and where The Beatles was stopped their live concert forever. This song uses many kinds of figures of speech in the lyrics hence writer finds figurative language types of this song they are hyperbole, paradox, cynicism, metonymy, synecdoche, irony, allusion, idiom, pleonasm, and personification.

\begin{tabular}{|c|c|}
\hline le 2 & \\
\hline Lyric & Type \\
\hline About a lucky man who made the grade & Hyperbole \\
\hline And though the news was rather sad & Paradox \\
\hline Well I just had to laugh & Cynicism \\
\hline He blew his mind out in a car & Metonymy \\
\hline He didn't notice that the lights had changed & Synecdoche \\
\hline $\begin{array}{l}\text { Nobody was really sure if he was from the house of } \\
\text { lords }\end{array}$ & Irony \\
\hline The English Army had just won the war & Allusion \\
\hline Having read a book I'd like to turn you on & Idiom \\
\hline Dragged a comb across my head & Pleonasm \\
\hline Found my way downstairs and drank a cup & Pleonasm \\
\hline Made the bus in seconds flat & Hyperbole \\
\hline Found my way upstairs and had a smoke & Pleonasm \\
\hline Somebody spoke and I went into a dream & Personification \\
\hline Four thousand holes in Blackburn, Lancashire & Hyperbole \\
\hline And though the holes were rather small & Paradox \\
\hline $\begin{array}{l}\text { Now they know how many holes it takes to fill the } \\
\text { Albert Hall }\end{array}$ & Cynicism \\
\hline
\end{tabular}

Table 2. Figurative languages found in "A Day In The Life"

In this song writer realizes that many kinds of figurative languages used in the lyric. Hyperbole, paradox, and pleonasm are often appears in the lyric. The theme in the song is about media and sociality.
2. The literal meaning in Beatles' Masterpiece especially "A Day In The Life" and "A Hard Days Night" 
In this opportunity, writer tries to explain what the literal meaning from word to word of Beatles' selected masterpieces songs in the lyric. The writer realizes that to understand the song is not only to know what figurative language types are found in the song, but also to know the meaning and the purpose of the lyric is.

\section{A Hard Days Night}

The song is cheerful and the contents of the song are tells about romance and sacrifice. Indeed, writer already found figurative languages of the song previously. Furthermore, writer will explain the intent of each lyric that writer hopes make the reader more understand about the theme of the song.

a. It's been a hard days night, and I been working like a dog

This lyric tells about how he feels tired through his daily activities. $\mathrm{He}$ feels as if working like an animal not as human being. An animal is usually described like a slave, and what the singer feels is just like what the animal does for his master, the singer thinks of himself as a slave not a professional worker who works on a regular working day.

b. It's been a hard days night, and I should be sleeping like a log
In this lyric, the singer increasingly emphasizes what he feels. $\mathrm{He}$ tells more the details of his exhaustion and depression of his job. The singer does not explain clearly what his profession is, but we can see that his job is like a subordinate class. The singer also says after finishing his works that he can sleep like a dead object, which will not move if not in touch, or in other words, because of his tired, perhaps he will sleep like a dead man.

c. But when I get home to you I find the things that you do

The singer explains that he goes home after working and meets his girlfriend. The lyrics tell what he sees and his girlfriend does at home. The lyric explains that the singer has a relationship with a woman who can be said that she is his girlfriend who always waits for him to come home after doing the daily activities.

d. Will make me feel alright

The describing of the singer in the lyric is like asking to himself that he will be fine after coming home. This lyric tells more what his girlfriend will do for him, whether to greet him warmly or there will be other problems when they meet.

e. You know I work all day to get you money to buy you things

The lyric is the answer as the reason he works so hard. The lyric 
make it clear that the singer works hard to please his girlfriend. The lyric explains the things that almost every woman in the world might like and he would like to give that joy to his beloved woman.

f. And it's worth it just to hear you say you're going to give me everything

This lyric is the singer's hidden desire for what he gives to his girlfriend. The singer wants his girlfriend be happy and more love him. He hopes that his girlfriend will do the same for him in different ways.

g. So why on earth should I moan, cause when I get you alone you know I feel ok

The lyric is the reason the singer stands the activity of the day. This because of his girlfriend's loyalty in accompanies him to face his hard day. Because the singer feels that his girlfriend is always there for him in any situation.

h. When I'm home everything seems to be right

This is a lyric which states more clearly the feeling of the singer after he arrives at home. The singer feels good, because his girlfriend is waits for him and helps to relieve his exhaustion. It seems that she has a perfect girlfriend, so the house is like a palace to him and he is like a king. i. When I'm home feeling you holding me tight, tight

This lyric is a confirmation of the previous lyric of what his girlfriend does. Holding hands in this lyric is can be means global, such as supporting him, standing beside him and encouraging him. Obviously, his girlfriend helps him to keep getting up and trying.

\section{A Day In The Life}

If the reader hears this song, then there will be different musical compositions, they make the song more special than other Beatles' songs. This song tells about the media that become the source of news and insight about the world and also tells about social life. Writer will interprets the lyric by understanding the generally words from the lyric that already wrote by songwriter so that the reader gets more understand about the theme of this song.

a. I read the news today oh boy This song begins with lyric that intend to explain that the singer reads one of the media which is commonly read by people, is newspapers. The lyric "Oh boy" is like hinting that the singer shares the news he reads in the newspaper.

b. About a lucky man who made the grade 
Actually, the news read by the singer is about the rich or successful man who manages to make success and wealth increases.

c. And though the news was rather sad

Actually, this lyric is an allusion to the news that the singer reads. Because in fact that the news is a good news

d. Well I just had to laugh This lyric is the reason why the news is considered sad news. Perhaps, the real intent is that the rich will get richer and the poor become poorer but not many riches help the poor, so that social problems arise.

e. I saw the photograph

This lyric explains the photo of someone in the newspaper that the singer reads.

f. He blew his mind out in a car From the lyric, the writer understands that the person in the photo thinks of getting out of his car. Just like something obstacle is around him

g. He didn't notice that the lights had changed

In this lyric the singer explains more about someone in the photo. Someone is not aware that what is there will change. Perhaps, word "lights" means like rules, life or something. Sometimes he could be up and down or he might die tomorrow.

h. A crowd of people stood and stared

The lyric describes the people who work as journalists look for news from a rich person.

i. They'd seen his face before The journalists have seen his face, because is not the first time they have interviewed a rich man, probably already the umpteenth time.

j. Nobody was really sure if he was from the House of Lords The lyric means the character of the rich man. Everyone no one knows he's a good person or bad, perhaps, the rich man helps the poor or never at all. The point of the lyric is not to see someone from what he has or what he shows but see what he does behind the scenes.

k. I saw a film today oh boy Still like in the beginning of the lyric that from this lyric the singer backs to share and tell about what he sees on Television.

1. The English Army had just won the war

The news on television is about the war that won by the English side. The true meaning of this lyric is to contain the criticism that winning a war or losing a war is equally a sad thing. The singer intends to declare that 
war is not a solution to end the race.

m. A crowd of people turned away This lyric is a continuation of criticism in the previous lyric that people can only turn their heads away from what affects the atrocities of war. They are happy about the war's wrath but some of them turn away because this is not really the real victory of mankind.

n. But I just had a look

From this lyric the singer is aware that he cannot do anything either. He can only see it on the news and can only rage inside his heart.

o. Having read a book I'd like turn you on...

This lyric seems to illustrate that the writer wants to change all this, all of public attentions and change social life for better and far from the things that already mentioned.

p. I read the news today oh boy The lyric tells back that the singer reads the news in a newspaper and he expresses his opinion about the news.

q. Four thousand holes in Blackburn, Lanchasire

The word "Holes" means broken roads as well as the facilities in the area at that time. In this lyric is indeed a singer like exaggerating but it is just as a confirmation sentence, so that the listener or music lover comes to realize the news referred to the singer.

r. And though the holes were rather small

The lyric continue to deliver in the previous lyric that the broken roads or facilities in the area are not too severe but for the singer, it is impact.

s. They had to count them all

This lyric becomes an affirmation that trivial or not but the problem around us that there must be improvement. From this lyric the singer teases the government that the government's responsibility is indifferent to the broken roads or facilities in the area.

t. Now they know how many holes it takes to fill the Albert Hall

The lyrics are still insinuating that governments should choose to improve facilities rather than build luxurious places but seem to ignore the people. In other words, build happiness above the suffering of others.

u. I'd love to turn you on

This lyric as a conclusion of all the lyrics that the reason he tells what he reads and knows. 
The purpose is to change bad culture in that era and keeps away the greedy attitudes. The singer invites to think the same as he thinks.

\section{The Moral Value of The} Beatles's Masterpieces especially "A Day In The Life" and "A Hard Days Night"

To complete the discussion in both songs of The Beatles, then is not complete yet if writer does not discuss about the moral value within. So, writer will analyze moral values in both songs. In "A Hard Days Night" writer finds the moral value of love and affection and moral value of togetherness and in "A day in the life" writer finds moral values of peaceloving and awareness a. Then writer will discuss more acutely in the next session.

\section{A Hard Days Night}

If we read the lyric, this song tells about a man who sacrifices for his girlfriend. He efforts to fulfill their needs and when he meet his girlfriend, he hopes that she will give a warmth and notice him for disappearing his exhaustion. He works at night and day, he works for all day long that is a precise description of his sacrifice.

From the story of the song, writer finds two moral values there are moral value of love and affection and moral value of togetherness.

a. Moral Value of Love and Affection

The lyric "You know I work all day, to get you money to buy you things" give a signal of love and affection which is showed to someone that he loves very much. So, he does difficult things to do by the power of love to prove his love for his special one. Sometimes, love able to make a lover become crazy, other statement is love is blind. Basically, love can make a person feels happy, energetic, and passionate.

Love has extensive meaning and universal. Love is not only belongs to lover, but also for close people around us like parents, brother/sister, best friend and God as the creator of this universe. Need to remember that love is entrusted, so we have to keep it good and love never creates problems in our life. Love is not always come with carrying happiness but sometimes it carrying revenge and pain.

As human being who more noble than love, because we should take control of love not love takes control of us, so love will appears in our heart become an affection to each other and this universe for peace. Writer quotes about the definition of love from former of The Beatles is John Lennon.

"Love is a promise love is a souvenir, once given never 
Priyoto \& Armando, P.,

The common used of figurative languages in Beatles' Masterpieces

forgotten never let it

disappear to the world, you

may be one person, but to one

person you may be the world"

- John

Lenno

$n$ -

a. Moral Value of Togetherness

This kind of moral value proved by lyric "When I'm home feeling you holding me tight, tight" it shows such a togetherness. The song shows togetherness from a couple. Their strong togetherness marks a good relationship. As human being we live to know each other, because the base characteristic of human being is sociality, it requires to build good relationship to each other. Togetherness is one of factors to survive. Togetherness in family, friend, and special one will make our life more meaningful.

Both of moral values in song A Hard Days Night, we can take a lesson from love and togetherness, because love without togetherness is an empty seat. Then both of them are important elements in human's life. If love contiguous with togetherness is will be a beautiful relationship.

\section{A Day In The Life}

This song tells about someone who expresses his opinion about the news that he gets from news media such as newspapers and television. He criticizes all the problems that appear as the main factors of social conflict and criticize the government. As a newsreader, he is only able to read and thinks without do anything, because all that things are controlled by law and the government is entitled to take care of them. The song likes the voice of ordinary people who argue and see from the reality.

a. Moral value of awareness

This moral value proved by the lyric "Four thousand holes in Blackburn, Lancashire And though the holes were rather small They had to count them all" and the lyric "I'd like to turn you on". The Singer wants to change or make sense of the way the government and its people look to be more sensitive to the situation that becomes a serious problem. Whether it's a trivial or a big problem, it's all necessary corrections and correct solutions to avoid a prolonged conflict.

From this moral value and the content of the story in this song, we can learn about our awareness of the circumstances surrounding which to give us more attention to the people in need and in trouble. We are often not to be aware of something that happens, we lack of empathy and social sense. We know that we are social beings that need each other to survive. 
We realize that today many people love to read the news but they can only smile or laugh at the news that concerns social issues and government without taking action and just rely on others.

\section{b. Moral value of peace-loving}

This moral value proved by the lyric "The English army had just won the war, A crowd of people turned away But I just had to look". It is indirectly a protest against war. Indeed, war has always been considered a powerful solution to solve the problems between countries, tribes, races and others in the matter of power, and the reason of defending the region. We have to know that there is a more beautiful option than war that is peace. War is nothing but bloodshed and the side of human cruelty that should be avoided. Choice of Peace will bring happiness which with peace, everyone will feel like brothers and protect each other and the virtue of Peace is to unite the differences.

Both moral values contained in this song are awareness and peaceloving is an important fusion in this world. Consciousness without peace brings only a feeling of blame. Peace when juxtaposed with consciousness will be an effective solution to face the problems that often occurs in this world. So each of us must have these two aspects is consciousness and peace. Writer will quote some lyrics from John Lennon after The Beatles split and decided a solo career. The lyrics are taken from "Imagine" song.

"Imagine all the people, living life in peace" - John Lennon -

\section{A. CONCLUSION}

From the analysis and the discussion, we can conclude that there are eleven kinds of figurative languages which Beatles used to express the song lyrics. They are simile, hyperbole, personification, metonymy, irony, allusion, paradox, cynicism, synecdoche, Idiom, and pleonasm. There are total 20 figurative languages found in both of Beatles' masterpieces song lyrics especially "A Hard Days Night" and "A Day In The Life". After conducting an analysis, in "A Hard Days Night" found simile and hyperbole two times and in "A Day In The Life" found hyperbole and pleonasm three times.

The total amount of hyperbole is 5 in both songs and followed by pleonasm 3 in one song used by The Beatles. So, this research conclude that the common used of figurative languages that mostly appear in Beatles masterpieces especially "A Hard Days Night" 
and "A Day In The Life" is hyperbole and followed by pleonasm.

In fact that The Beatles use a lot of themes about love and life which in both songs are commonly used lyrics containing hyperbole and pleonasm. In both of The Beatles songs, hyperbole is used to describe something that cannot be expressed by words and pleonasm as an affirmation of the lyrics.

\section{BIBLIOGRAPHY}

Bentham, Jeremy. 2010. The Principles of Morals and Legislation. Amherst: Prometheus Books.

Davies, John. 2009. Lyrics and Limericks.United Kingdom: Pneuma Springs Publishing.

Earle, William. 1992. The Life of the Transcendental Ego. New York: State University of New York Press.

Fiether, Josep Francis. 1996. Situation Ethnic: the new morality. Philadelphia: Wstminster Press.

Hazlitt, Henry. 1988. The Foundations of Morality. New York: The Foundation for Economic Education.

Jacques, S Benninga. 1991. Moral, Character, and Civic Education in the Elementary School. New York: Teachers College Press.

Kumar, Ranjit. 2005. Research Methodology A Step By Step Guide for Beginners. Second

Edition. Singapore: Person Education.

Lind, George, Hans A. Hartmann, and Roland Wakenhut. 1985. Moral Development and the Social Environment. Chicago: Chicago, Illinois.

Mpanza, Funda. 2014. Turn Your Life Into a Masterpiece, enjoying a life of

fulfillment. Bloomington: Author House.

Patton, Michael Quinn and Michael Cochran. 2002. A Guide to Using Qualitative Research Methodology. Medecins Sans Frontieres.

Recanati Francois. 2004. Literal Meaning.UK: Cambridge University.

Roberts, Jeremy. 2011. The Beatles, Music Revolutionaries. USA: Twenty First Century Books.

Russell, Reaske Christopher. 1966. How to Analyze Drama. New York: Monarc Press. 
Journal of English Language and literature

Volume 3, Issue 2, September 2018

Steinberg, Mark D. 1992. Moral

Communities.

California:

University of California press.

Stern Josef. 2000. Metaphor In

Context. London: Massachusetts

institute of technology
p-ISSN 2540-8216, e-ISSN 2654-3745

https://journal.stibaiec-jakarta/ojs/index.php/jell

Westmoreland, Jahne Jahmal.

2010.Lesson in Lyric. USA

Bloomington: Authorhouse.

\section{Internet}

Figurative Language Worksheets |

Definition \& Examples -

$\underline{\text { KidsKonnect }}$ 